\title{
Humour of the intimate: Female humour and women policies in Turkey
}

\author{
Şenay Yavuz Görkem \\ Maltepe Univesity, Istanbul, \\ senayyavuz@maltepe.edu.tr
}

\begin{abstract}
This study focuses on the women policies of the Turkish government and the female humour that is created in response to these policies. A humour magazine is used as the main source since this specific magazine, which is named Bayan Yanı (The Seat Next to a Lady), has the privilege of being the only humour magazine created solely by female caricaturists and writers in Turkey. Six samples of female humour related to intimate matters are selected purposefully from 16 issues of this magazine published between January 2015 and June 2016 and analysed in content, tone, and function. The aim is to develop an understanding on female humour, especially the humour of the intimate, created to lead the public to question the effectiveness of political decisions and practices related to women policies.
\end{abstract}

Keywords: Women policies, political humour, female humour, semiotics.

\section{Introduction}

Administrative power is secured and reinforced by the execution of political power on different aspects of human life; institutions such as family, religion, and school play a substantial role in the propagation of state policies stealthily and in guiding people into internalising these policies all over the world (Unal \& Cindoğlu 2013). Turkey is not an exception. The early republican governments attempted to create a free, modern woman profile that was visible in social life but still reflected traditional values by remaining asexual in public. However, these attempts did not mean that the women were liberated. For instance, the formation of the Party of Republican Woman was not permitted by the state officials and Women's Federation of Turkey was banned (Ince et al. 2009: 540-541). The Justice and Development Party (JDP), which has been the ruling party in Turkey since 2002, on the other hand, has been defining the ideal woman through traditional and religious values (Çitak \& Tür 2008). The fact that demographic policies that have been executed since the foundation of the Republic of Turkey by different ruling parties either aimed to prevent abortion and promote maternity or induce family planning when faced with rapid population growth illustrates that even women's reproductive capacities have been and will always be a domain for social engineering policies (Unal \& Cindoğlu 2013: 21). 
Humour of the intimate is used here to refer to humour that is generated by women in reply to these social engineering policies. To be more specific, it covers humour produced in response to state policies regarding intimate and family relationships, gender roles, sexualities, and reproduction. Intimate and family relationships are covered in relation to the notions and norms of marriage, separation, and divorce, and how these notions are dealt with by the political authorities. Gender roles are studied with reference to governmental statements about what males and females can and should do. Sexuality refers to normative construction and regulation of how individuals are regarded as sexual objects within a political environment. Reproduction refers to state policies on reproductive choices, rights and freedoms on matters such as family planning, abortion, and birth control.

The main purpose of the present study is the analysis of six caricatures that capture the political humour that Turkish women produce in response to social policies of the JDP, especially the policies related to women's intimate matters. The aim is to develop an understanding of female humour, especially of the humour of the intimate, created to lead the public to question the effectiveness of political decisions and practices related to women. The study presents an analysis that explores the opposing stance of a specific humour magazine towards the women politics of the government in Turkey, and carries the potential to fill a gap in the field as research on oppositional humour in Turkey is scarce. Research on oppositional humour carries significance as it has the potential to reveal the reasons and intentions behind the produced piece of humour, and helps clarify the criticism reflected in a comprehensive way. Research on female humour is limited as well, and this study aims to contribute to the existing literature on female humour through an analysis of female humour in Turkey.

\section{Functions and theories of humour}

Veatch (1998: 164) asserts that "humour occurs when it seems that things are normal while at the same time something seems wrong". Violation of morality or a principle is a prerequisite for humour to occur within this framework. However, this violation should be perceived as acceptable by the individual for an input to be humorous. Political humour can be viewed within this perspective. Dissent, or in this sense, the perception of the violation, is transformed into a less painful form when it is presented in a fictional format and thus people become able to laugh at a matter that they would otherwise be unable to, because the violation in real life is too painful as it attacks a principle that is held as precious for a reason.

As Kotthoff (2006: 5) states, "by violating norms and creating unconventional perspectives, humour certainly influences norms. It creates new, unusual perspectives on the object and thereby communicates sovereignty, creative power and the freedom to intervene in the world". That is why dissident people use humour to challenge perspectives created by power authorities and promote 'their norms' as opposed to the norms imposed by power authorities. They also use humour as a means for undermining power structures and convincing their audience that it is their interpretation of reality that is legitimate, not the interpretations imposed on them. As Tsakona and Popa (2011: 13) assert, humour can also be used to lead audiences to question the effectiveness of political decisions and practices as it is a viable means for revealing the inconsistencies and inadequacy of political practices. Another important reason why humour is a popular discourse in expressing political dissent is the feel good factor. As Badarneh (2011: 305, 307) notes, just like a carnival does, the use of humorous content helps to create a second world alternative to the one created when people feel oppressed and acts as a means to regain self-respect and the spirit of freedom.

Humour is a means of regaining self-respect and the spirit of freedom because it can be used as "a safe release for aggressiveness against a superior force" (Badarneh 2011: 306). 
Humour is perceived as harmless, playful, pervasive, and positively evaluated, and it turns political critique into a respectively 'humble' game, as jokes may exonerate "individuals from any guilt that might otherwise result from the conversational articulation" of the same content in a more formal tone (Davies 1998: 175). Individuals can express themselves directly and openly through humour, which is by itself a source of self-respect and the spirit of freedom. It is used to cope with asymmetric status relationships and to disguise aggression as humour has a metapragmatic function of implying what is said is not totally serious (Kotthoff 2006: 7, 11). Humour makes it possible for individuals to reply back to people who are of a higher position in the social hierarchy, for example, politicians. It is not likely for individuals to engage in face-to-face dialogue with politicians and express their criticisms openly due to differences in status. However, under certain circumstances humour makes it possible for dissident people to advocate for their ideas and challenge the norms imposed on them via jokes, caricatures, and other humorous material. They can also disguise the aggression reflected in their criticisms by using humour.

Politicians use humour as part of their rhetoric and the public also uses humour to criticize political practices. Humour magazines play an important role in this respect in Turkey by acting as the representatives of dissident people; caricaturists have an adversary profile and they are experts in producing political humour. Caricatures that target political figures serve the purposes of bonding and biting. They build rapport with the readers and express aggression towards political parties (Hay 1995: 9). Caricatures unite the creator of the caricature and the readers as they make fun of and laugh together at the political figure or a specific policy depicted in the caricature. Being able to laugh at the same thing is a sign of shared views (Veatch 1998: 187, 209, 210) and this creates intimacy. They also have a biting effect as the caricature reflects teasing. Teasing is associated with standing up for oneself and fighting if necessary (Boxer \& Cortés-Conde 1997: 279-280). Teasing is also related with power and solidarity (Hay 1995: 9). Thus, it can be concluded that caricatures that criticise the women policies in a country for example, lead to bonding among the audience as people feel that they are not the only ones thinking that way, that they can stand up and fight, and that there are people advocating for their rights.

Humour theories provide a fertile ground for understanding why humour is used so often for criticising political practices. Relief theory focuses on the need to reduce physiological tension and defines laughter as a release of repressed energy (Hay 1995: 7). According to the theory, suppressed desires and socio-cultural inhibitions cause nervousness in people and laughter acts as a healer. Sexual and aggressive humour can be explained by relief theory (Buijzen \& Valkenburg 2004: 147). It would not be wrong to claim that the female humour analysed in this study can be a reflection of the tension that women experience due to the policies and norms imposed on them. When the tension and aggression felt cannot be expressed openly due to various reasons, humour acts as a safety valve. It also acts as a healthy mechanism for normalising a situation that is beyond our control and convincing oneself that it is not threatening (Veatch 1998: 204)

Superiority theory has a more emotional focus and explains the source of laughter as the need to feel superior to the party that is being laughed at. The producer of humour feels superior, right, and triumphant, while the target of humour is positioned as inferior, wrong, and defeated. The party being laughed at is seen as the one that violated a principle and thus failed, not the one laughing; that is why laugher becomes legitimate and normal even if the situation depicted in the humour source is painful. The laugher is positioned as an outsider and as a result has the luxury of making fun of things that would be painful if positioned as inside the humorous situation (Buijzen \& Valkenburg 2004: 148; Hay 1995: 7; Veatch 1998: 189). The humour analysed in this study can also be viewed within this framework because people feel the need to feel superior when they feel desperate and trapped. Incongruity theory 
suggests humour stems the fact that people find the violation of an expected pattern amusing. Humour based on absurdity, nonsense, and surprise can be explained by incongruity theory (Buijzen \& Valkenburg 2004: 148).

\section{Women, policies, and JDP}

The reforms that JDP initiated in terms of gender politics, especially during the early period of its rule and as part of the attempts to a European Union membership, should be noted here. The party obliged municipalities with more than 50,000 inhabitants to set up women shelters, formed the Parliamentary Commission for the Equality of Opportunity for Women and Men in 2009, changed the penal code and recognised sexual crimes as crimes against the individuals/crimes against the inviolability of sexual integrity, terminated provisions that provided rapists with the possibility of avoiding legal punishment by marrying their victims, and eliminated discrimination against non-virgin and unmarried women (Coşar \& Yeğenoğlu 2011: 562). The party also ran a nationwide campaign to encourage the schooling of girls, extended the duration of the paid leave for working women after giving birth to a child, established family courts, and formed a parliamentary commission to investigate and solve the problem of 'honour' killings (Çitak \& Tür 2008: 456). However, the fact that the party does not monitor and control the execution of the amendments that it has passed strictly leads oneself to questioning the effects of these reforms (Coşar \& Yeğenoğlu 2011: 562). For example, out of the 244 provinces with 50,000 or more inhabitants only 54 had women shelters by October 2009 (Coşar \& Yeğenoğlu 2011: 563). The party does not exhibit an open attitude towards women's civil societal activism or engage in dialogue with women's rights organisations, and warns women not to be slaves to the feminist ideology instead (Onar \& Baç 2011: 383).

The JDP is a political party that does not deny its attachment to religious norms and values; these norms and values have increasingly become part of the party's rhetoric. JDP has been the ruling party since 2002 and has idealised women as sacred mothers, foundation stones of the family, and the protectors of the moral, cultural, and social order (Acar \& Altunok 2013: 18). Leaders of the party portray women as mothers whose main source of power are traditional and moral values and not as independent individuals (Çitak \& Tür 2008: 461). The renaming of the 'Ministry of Women and Family Affairs' as 'Ministry of Family and Social Affairs' by the JDP indicates how women are positioned by the party. The renaming suggests that it is not necessary to pronounce the word women as family affairs cover women affairs anyhow.

The fact that the JDP has been propagating patriarchal religious values via the public bureaucracy and the educational system has led to concern in the non-conservative domain of the society and the feminist organisations (Arat 2010: 869). The main contention underlying the grounds of this concern is that this religious outlook on life promotes traditional roles for women, limits their control on their bodies, and dictates the moral and social norms for women (Arat 2010: 881). It is not argued in this paper that Islam is less supportive of gender equality and women's liberalisation as opposed to other religions. In fact, it is asserted that Islam blesses women with the same rights and status as of men (Engineer 2008) and that Qur'an is particularly solicitous about women's well-being and development (Hassan 1995). It is the variance in the interpretations of Islamic ideals and discrepancies in practice that grant women varying degrees of freedom and thus cause concern. For example, Saudi Arabia is a Muslim country and there are many practices that restrict women in a secondary role: women are excluded from social life, do have limited educational opportunities, and are not allowed to drive (Hamdan 2005). 
Although almost a century has passed since secular and progressive reforms with regard to family and women took place, customary and religious practices are still more influential in the daily lives of the majority of the women in Turkey (Ilkkaracan 1998). Women are traditionally and religiously expected to play a subsidiary role in the public and this is even reflected in proverbs such as 'A woman's hair is long and mind is short', 'Women are incomplete men' and 'The male dog gets close to the she-dog only if she wags her tail'. That is why women are considered to be guilty if they are sexually abused or raped. The so called 'honour' killings are still prevalent in many parts of Turkey and women are killed if they are considered to threaten male honour (İnce et al. 2009: 547). Turkey is unfortunately a country where domestic violence, child brides, polygamy, and forced marriages are still prevalent (İlkkaracan 1998; Turam 2008) and, as the Global Gender Gap Reports of the World Economic Forum in 2006 and 2015 indicated, the relative gaps between women and men across key areas of health, education, economy, and politics in Turkey are problematic. Turkey was ranked 105 in 115 countries, between Burkina Faso and Mauritania, in the 2006 report and 130 in 145 countries, between Benin and Guinea, in the 2015 report. According to the 2015 report, Turkey was the country with the worst performance in its region of Europe and Central Asia.

One cannot avoid the thought that women can find themselves in a very undesirable position if the government empowers and propagates customary and religious practices, and the values underlying the grounds of these practices, given the factors mentioned above. The early republican governments tried to replace these practices with the civil code, granted women equality in many matters, tried to create modern, secular, and educated Turkish women, and yet failed to wipe out the influence of these customary and religious practices. It should be noted here that the efforts of the early republican governments were also a strategic attempt to create the modern Turkish women that they needed for their top-down modernisation project (Kaya 2015: 54). Ince et al. (2009: 537) assert that during the modernisation process, women "were turned into asexual beings whose cultivation and emergence as individuals in the public sphere depended on their liberation from femininity". That might be why it was the JDP government that recognised sexual crimes as crimes against the individuals, terminated provisions that provided rapists with the possibility of avoiding legal punishment by marrying their victims, and eliminated discrimination against non-virgin and unmarried women, and not earlier republican governments. While earlier republican governments did not need to change the related civil code and provisions for their strategic aims related to women, in their effort to join the European Union, JDP had to. Returning back to the discussion on the strength of customary and religious practices versus the civil code, the current situation proved that rights on paper bear no significance unless the execution of these rights becomes an internalised part of social life. This shows how powerful those customary and religious practices are.

It is not uncommon for the president, prime minister, or other governmental figures to express what women should or should not do, encourage maternal roles and patriarchal values, and disregard women's right to control their bodies and lives. For instance, the former Prime Minister, current President Recep Tayyip Erdoğan has been advising women to give birth to at least three children (Kaya 2015: 60). He defined abortions as murders and opposed caesarean births claiming that these were steps taken to prevent Turkey's population from growing further (Unal \& Cindoğlu 2013: 22). The Directorate of Religious Affairs publicly announced that Muslim women should wear a head scarf as it is a religious pre-requisite, not to use perfume outside their homes, not to remain alone with men that are not relatives, and not to flirt (Arat 2010: 875). Likewise, a prayer leader commended the men at the mosque for a Friday sermon not to let their wives work outside the home as this will make them more prone to adultery. This prayer leader was only moved to another mosque as a punishment (Arat 2010: 
875). Moreover, one of the mayors of Istanbul published a pamphlet on how to maintain an ideal marriage to be presented to newly married couples and advised women to be subservient to their husbands and men not to beat their wives unless necessary (Arat 2010: 876). These examples were not included to suggest that all JDP party cadres support repressive views in relation to gender politics; nor shall they be viewed as an attempt to denigrate the JDP by just focusing on the negative and disregarding the positive practices. The reason why these statements were included in the present paper was to display why concern about regressive policies on women was fuelled despite the fact that JDP had initiated many reforms in relation to gender politics.

\section{Female humour}

In the past women were expected to smile receptively to joking men and were often the objects of humour, not the subjects. One reason is that it was considered inappropriate for women to play the clown and fool around; women were expected to be pretty, modest, and decent. However, in today's world, women have become the subjects of humour, and jokes at the expense of men, even at the expense of politicians, have become commonplace (Hay 1995: 26; Greenbaum 1997: 119; Kotthoff 2006: 5, 16).

Research shows that female humour differs from male humour in many respects. Female humour reflects self-disclosure, reciprocal sharing, intimacy, and familiarity. Women share their disappointments, hardships, failures, and misfortunes with others through humour. These cooperative forms of humour have a healing function as women realise they are not the only ones going through those processes and that they are 'normal' (Kotthoff 2006: 15). Women's tendency to joke about themselves and their experiences leads to the establishment of common ground and intimacy (Hay 1995: 29). This tendency may be the reason why women use anecdotal humour more often than men do (Hay 1995: 83).

Female humour seems to be mainly focused on internal issues and the main topics are "relationships, emotions and politics as it relates to feminism and body image" (Greenbaum 1997: 117-118). Women prefer absurd or nonsensical humour to sexual humour as opposed to men and do not appreciate aggressive humour as much as men do (Brodzinsky et al. 1981; Johnson 1992: 580; Weinberger \& Gulas 1992: 52; Buijzen \& Valkenburg 2004: 152). Research also indicates that women are more prone to observational humour than men, whose humour is more performance-based (Hay 1995: 83, 86).

\section{Bayan Yanı}

Bayan Yanı is a humour magazine that is produced on a monthly basis by women writers and caricaturists since March $8^{\text {th }}, 2011$ and the magazine claims to be the only humour magazine in the world produced by women only. It was planned as a special issue of Leman, which is one of the most important humour magazines in Turkey; however, the issue published on March $8^{\text {th }}, 2011$ was so popular among the readers, editors, and the caricaturists that the Leman administration decided to continue with Bayan Yant. An average issue consists of 32 pages which are allocated to caricatures, strips, and columns.

The name of the magazine, meaning "The Seat Next to a Lady", connotes much information to the audience. The use of the word lady reveals in what ways linguistic choices connote how women are positioned in a society. It is still considered as inappropriate to call a woman a woman as the word itself is considered to be related with sex. In Turkey, the word woman is associated with virginity. An unmarried woman is called a girl unless her virginity is questioned. That is why bayan "lady" is used as a substitute for woman, which is widely 
criticised, especially by feminists, with the claim that the use of the word is a way to impose on women the idea that they should be ladylike and inhibit their sexuality. The name of the magazine might be interpreted as an indirect criticism of this matter.

Another connotation that the name of the magazine suggests is solidarity among women. When women buy coach tickets, they buy the tickets for seats next to a lady. This practice is long established in order to make sure that 'ladies' will not have to sit next to a man for hours of travel. This practice also reflects sexual discrimination, as it is implied that women and men cannot travel together; that women are not safe when they sit next to a man they do not know. There have been many instances that proved this point of view to be right; however what is criticised is that measures should be taken by governments to change the current situation and that women should be safe when they are not travelling next to a lady as well. From another point of view, the term the seat next to a lady also connotes a journey of women in solidarity which is very consistent with one of the most obvious functions of humour, creating solidarity.

The 16 issues of Bayan Yant, from which six caricatures were selected for analysis in this study comprised a total of 356 caricatures, 215 columns, and 206 strips. Approximately one third of the magazine is dedicated to political humour and the main topics were domestic violence, sexual abuse of women and children, child brides, women murders, and the hardships of Syrian refugees. The topics that the caricatures not targeting politicians and other prominent figures for their actions and statements frequently covered, involve wifehusband/girlfriend-boyfriend interactions, women's characteristics, interactions among women, advice from women to women, and light-hearted anecdotes. Caricatures devoted to wifehusband/girlfriend-boyfriend interactions depicted matters such as marriages, romantic expectations versus realities, extreme jealousy of women or men, tricks of women, sexuality (women trying to avoid sexual intercourse or to seduce their husbands), ex-wives, cheaters, role expectations, and women trying to 'educate' men. Humour related to women's characteristics focused on women's moodiness, capriciousness, inconsistency, instability, and worrisome and dissatisfactory nature. Caricatures on interactions among women could be divided into three: those with the theme of cooperation and support between women, those revealing conflict and the ways women pulled each other down (e.g. power play between mother-in-laws and daughter-in-laws or between neighbours), and those that focused on ridiculous codes of conduct between women, such as being pitiless when gossiping or being too possessive with best friends. There were also caricatures allocated to raising awareness; these were mostly in the form of advice from women to women, usually from the old and experienced to the young. Women were advised on many matters from being strong, independent, and having self-respect to not being confused by male perception on matters such as sexual abuse or the perfect women. Light-hearted anecdotes included success stories of women, instances of women in unity and solidarity and the stories of a crabby old woman who could accomplish anything. There were also columns that dealt with topics such as feminism, maternity, biological clock versus career decisions, menopause, and the LGBT movement in a more serious tone. As aforementioned, this study focuses on six political caricatures reflecting female perspectives on government policies related to intimate matters.

\section{Methodology}

Semiotics is the key to analysis in the present study. Purposeful sample method was used and samples of female humour that were related to the politics of the intimate were selected from the most recent 16 issues of the magazine. A total of six caricatures, five of which were created by Feyhan Güver, one of caricaturists of the magazine who focuses on politics of the intimate, was selected for the analysis. The creator of one of the caricatures was anonymous. 
These six caricatures were selected as these caricatures suited the purposes of the study. It should be noted here that the selection was carried out according to the content of the caricatures and not the caricaturist that created them. Humorous content that was not totally bound to the Turkish culture and had the potential to be transferred to people outside the Turkish society was chosen. As a second step, the humour reflected in these caricatures was compared to the humour in the 16 issues of the magazine which comprised 356 caricatures, 206 strips, and 215 columns produced by numerous female caricaturists and writers.

Verbal and visual signs in the sample caricatures selected from Bayan Yanı and the referents to which these signs call attention were analysed (Sebeok \& Danesi 2000: 13-14). Barthes' model of semiotics served as the framework of this study. Barthes' concepts of denotation (i.e. the literal meaning) and connotation (i.e. the secondary, socially created meaning that needs to be interpreted by the audience) were used as a means of content analysis (Barthes 1966; 1977). The female humour produced as criticism of women policies of the government was analysed in tone, function, and content to deepen our understanding of such oppositional female humour on matters of intimacy and to be able to compare this type of humour with other kinds of female humour published in the magazine. In terms of tone, two categories were used: inoffensive or offensive (Veatch 1998). With regard to function, three main categories were adopted: creating solidarity, maintaining or creating power, and satisfying psychological needs, to be more specific, the needs of defending oneself or coping with a stressful situation (Hay 1995: 98). Solidarity can be created by humour that reflects sharing sensitive information about oneself or highlighting similarities between self and others, which both enhance mutual trust and common points. Maintaining boundaries by making fun of outsiders, for example, and teasing that reflects a joking relationship are other ways of creating solidarity. Humour can create control when it aims to control the behaviour of the audience by demeaning someone in the audience, giving an aggressive message or teasing a group member. With regard to psychological functions, humour is used as a shield when one uses it for identifying a weakness and making fun of it before anyone else does for protecting the self. It is also utilised for coping with problems as joking about something gory, threatening or depressing is expected to help people cope with the problems (Hay 1995: 98110).

To clarify and summarise the means of analysis in a nutshell, it can be stated that Barthes model of semiotics was used to analyse the content, Veatch's model was used to analyse the tone as well as the normality and violation factors in the structure, and Hay's model was used to analyse the function. Political and cultural referent systems by which verbal and non-verbal signs can be interpreted were unveiled during the analysis (Penn 2000: 244).

\section{Analysis}

Caricatures that are produced as criticism of political practices are given on the cover page and the following two pages, which are named Bayan Yani Actual. One obvious difference that can be observed between these caricatures and the others is that they have captions which clarify within what specific framework the caricature should be interpreted. The other caricatures and strips are not introduced with a caption; this indicates that the women caricaturists and writers of the magazine are well aware of the situational nature of humour. The main topics that are covered go in line with the actuality of the country and include topics such as sexual harassment, child, baby, and animal abuse (in general and especially in government bodies such as schools, dormitories, prisons), domestic violence, women murders, birth control, virginity, rape cases, women's liberation, annoying jurisdiction processes for cases relating to violence against women and children, and norms and values imposed on women by politicians 
via the education system and religion as well as the public itself. Some norms that are criticised in the magazine are: women and men should not shake hands, as contact between men and women is not encouraged by the religion; women and men are not equal and should not contact each other much in social life; women should not laugh in public; a pregnant woman should wear clothes that would not call attention to her pregnancy; if a woman wears revealing clothes or goes out late it is normal if she is abused and domestic violence is normal and accepted by our religion. Other kinds of humour covered in these pages but not directly related to women policies are related to issues such as secularism, the educational system, the terrorist group PKK and the Kurdish civil people in the Southeast Anatolia, deaths of innocents (both soldiers and civilians), bribery and corruption news about the government, and Turkey's public diplomacy on Syria.

The first caricature included in the sample of this study was introduced with the caption One of the suggestions of 'the committee on divorce' is to base psychological guidance and counselling to families on religious principles.

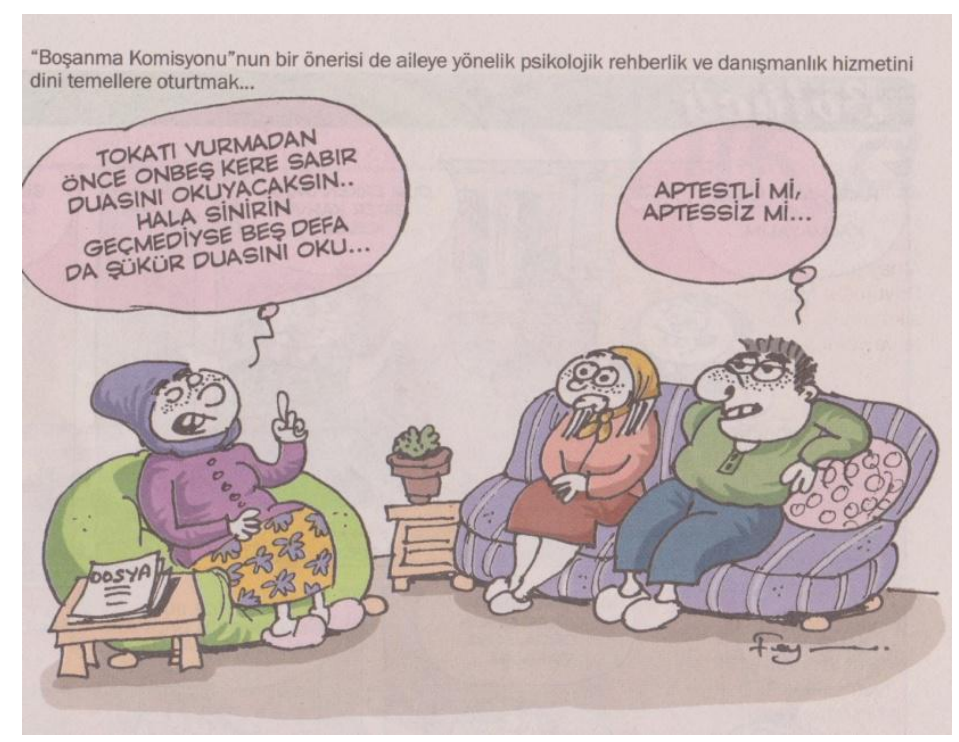

Figure 1. "Should I perform an ablution beforehand or not" (Bayan Yanı Humor Magazine, 2016, June, 54: 3, reprinted with the permission of Feyhan Güver, the creator of the caricature.)

The caricature depicts a family counselling session that is based on religious principles. The session takes place in the couple's home as signified by the basic furniture that is colourful (green and purple sofas, a pink cushion). The items in the room and the way the family is dressed connotes that they represent the average patriarchal Turkish family; for example, the husband leans back comfortably on a cushion but the woman sits upright. The counsellor wears a scarf which denotes that her outlook on life has a religious basis and would consider basing psychological guidance and counselling to families on religious principles as proper and right. She says: "You should say the prayer of patience fifteen times before you slap; if you are still angry, say the prayer of gratitude five times"; and the husband just asks: "Should I perform an ablution beforehand or not?" The wife, who wears a scarf and reflects a traditional and religious outlook on life as well, is portrayed as one with a subsidiary role as she is the one who listens to the conversation that is directly related to her life but cannot join it or speak up for her rights. She just listens to the conversation in a confused manner. Body language of each individual reveals hidden meanings. The counsellor's authoritarian body language also connotes a criticism on the authoritarian manner of the Turkish government. The body 
language of the husband (hands at his waist - a symbol of aggression) demonstrates that he is comfortable with the session and the specific advice. He is ready to slap his wife and he perceives it quite normal as the reaction is just a question about performing an ablution beforehand or not. The wife listens with her hands clasped, which is a sign of submissiveness.

The caricature can be viewed as a reaction triggered by the concern that the Turkish government attempts to incorporate radical interpretations of religion into Turkish women's marriages. Basing family counselling on religious basis does not necessarily mean advising men to exert violence on their spouses. Religion can be used as a source of counselling, especially in a country where it plays a major sociological role. Religion based family counselling need not be reactionary. It is not uncommon in other countries either. For example, priests have been trained to provide marriage counselling for decades in the USA and the UK (Herbert \& Jarvis 2013). However, as religion and the status of women have become negatively correlated in the minds of many people in Turkey, it is possible that the suggestion of the committee on divorce evokes a scene similar to the one portrayed in the caricature in the minds of this group. The caricature has an offensive tone and demonstrates that Turkish men are already prone to domestic violence and that the government should not encourage them more by promoting religious values that reinforce the patriarchal nature of families and subsidiary roles imposed on women. The caricature aims to satisfy a psychological need: the need to cope with the anxiety that the government policies on women create and to provide relief. The caricature demonstrates what might happen if the suggestion of the "committee on divorce' is put into practice in a fictional format. This fictional situation also creates absurdity and enhances the humour provided in the caricature by presenting incongruity. The prerequisites for humour are all present. Everything seems normal but there are many violations. A counsellor encourages a husband to slap his wife if he still wants to, after saying some prayers, which is not reasonable. The husband finds this suggestion reasonable and asks "Should I perform an ablution beforehand or not?", which is another violation. The fact that the wife just listens and does not react is another violation. The caricature presents a fictional situation and helps women to laugh at things that they in fact see as threats. In other words, it serves the function of satisfying a psychological need, the need to cope with something unpleasant by joking about it. The caricature also serves the function of solidarity as the suggestion of the committee on divorce is being teased, and hence the audience feels as a part of an intelligent group who laughs at the unwise other. Davies (1998: 65) explains this function as follows:

we may see jokes about stupid outsiders as an affirmation of the value of rationality, efficiency and applied intelligence on the part of the joke tellers, for any failure to live up to and conform to these qualities is ascribed to outsiders and then subjected to ridicule. It is they who are comically stupid and irrational and we who are intelligent, skilled and organised (emphasis in the original).

The caricature in Figure 2 (below) depicts a conversation between an old and a young woman. The old woman says "I gave birth to Şükran when plum trees fructified and I gave birth to Şevket during the harvest", which is not uncommon as Turkey has been an agricultural society for long and the times when trees fructified or when the crops were harvested were the main cornerstones of social life. People still use these terms to refer to specific periods of time in some parts of Turkey. That is why the time referent used in the words of the old woman are used to connote the effect of social determinants of women's perception, like the way a woman associates the birth of their children with agricultural processes which confluence with nature. The old woman sits comfortably and displays a positive facial expression. The words of the younger woman "I gave birth to Ulaş when abortion was banned and I gave birth to Beren when coil contraception became paid", on the other hand, signifies that some women in 
contemporary Turkey associate the births of their children with government policies on reproduction. She looks uneasy and anxious as opposed to the older woman. Her associations related to motherhood are not related with natural concepts such as fructifying trees or the harvest, but with politics. The caption above Abortion, which should be practiced free of charge, has been terminated stealthily without any legal basis, and coil contraception, which should be an unpaid service became a paid one clarifies the effects of politics on the reproduction of women. This caricature has a less offensive tone and humour here serves a relieving function. It reflects self-disclosure and sharing. This type of humour has a healing function as women become able to laugh at things that distress them and as they realize they are not the only ones going through those processes. For these reasons, it can be argued that this caricature serves the functions of creating solidarity and satisfying psychological needs.

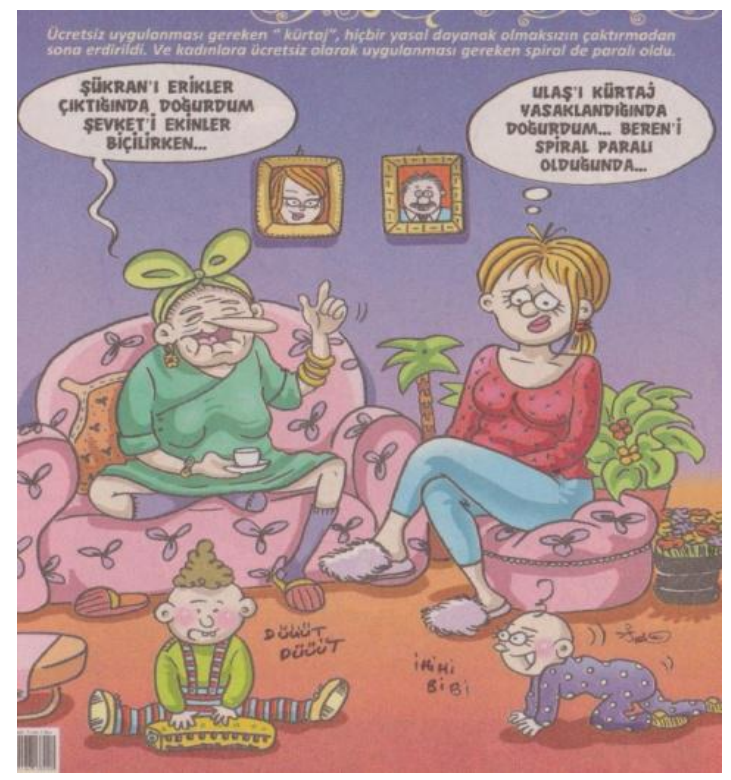

Figure 2. "I gave birth to Şükran when plum trees fructified and I gave birth to Şevket during the harvest", "I gave birth to Ulaş when abortion was banned and I gave birth to Beren when coil contraception became paid" (Bayan Yanı Humour Magazine, 2015 January, 38: 11, reprinted with the permission of the magazine administration.)

The caricature in Fugire 3 displays a park scene. Two women are talking to each other, the one with the kid asks the pregnant one about the gender of the baby that she is expecting. As the woman talk, the man on the bench wonders if the pregnant woman is a 'married pregnant' or a 'prostitute pregnant'. The man depicted in the caricature is a well-known pro-government figure, especially for his role in one of the very important cults of Islam in Istanbul. He has written many books on Islam and is a venerable figure, especially in the religious circles. He often claims that he is held responsible for words he did not utter and his statements are presented in a distorted way in the media. In one of the TV programmes he was invited, he said:

It is against our moral values to declare loudly about pregnancy. Women shouldn't wonder in streets while pregnant. First of all, it is not aesthetically pleasing. Women around 7-8 months of pregnancy hop on their husband's car to get some fresh air. They can go out in the late afternoon... But now, everything is everywhere. This is not decent. This is not realism. This is pure indecency. 


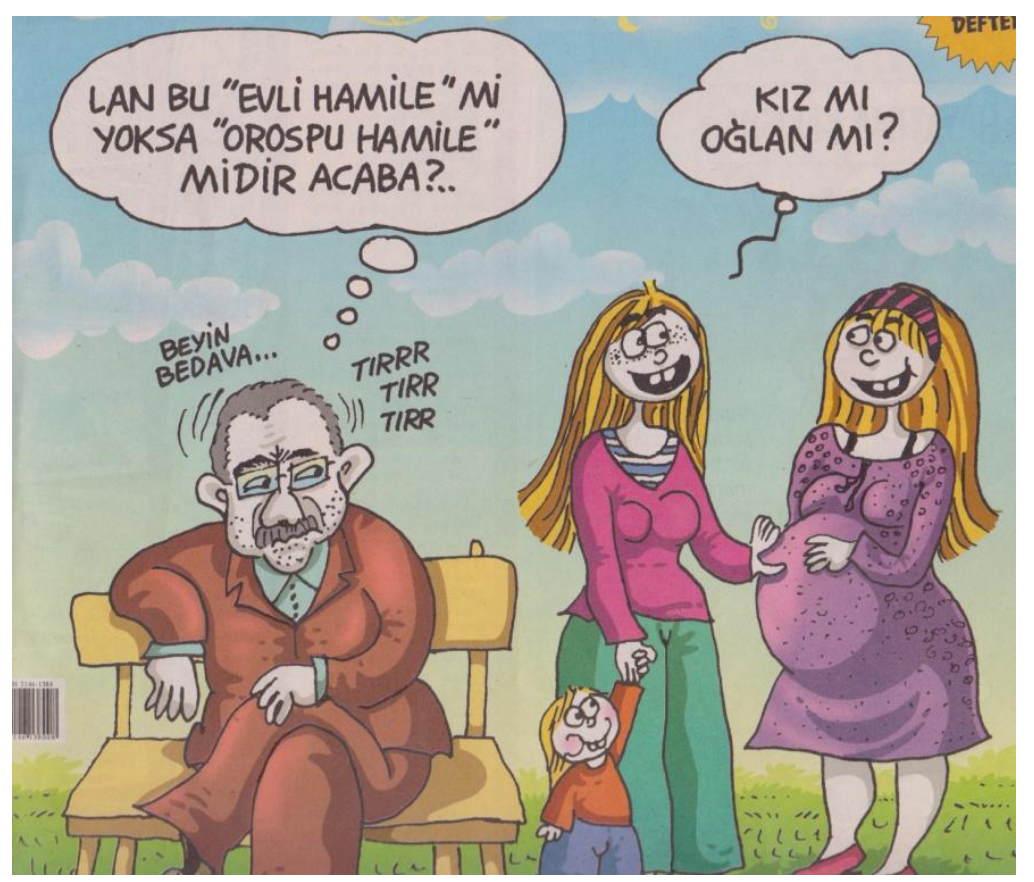

Figure 3. "Is this a 'married pregnant' or a 'prostitute pregnant'?" (Bayan Yanı Humour Magazine, 2015 January, 38: 1, reprinted with the permission of Feyhan Güver, the creator of the caricature.)

And the TV presenter said "God bless you" in response, which was as shocking as his statements for many Turkish people (Bianet 2013). In an interview conducted with him later about his statements he said: "I did not say pregnant women should not go out, I said they should not expose it, they should hide it". He further added: "There are women who say they will not get married but they will give birth and they call this freedom. Freedom! I will spit on the world in which prostitution is called freedom. This is prostitution" (Par 2014). The caricature is designed in a way that two different statements of this famous and respected figure, one suggesting that pregnancy should be kept private and the other one suggesting that a single woman's claim to the right for pregnancy is immoral, are intertwined on purpose. The impression that the caricature creates is that he associates pregnancy with prostitution. The thought bubble in the caricature reflects a criticism of his way of thinking as no one would think of prostitution when one sees a pregnant woman; this is the main violation in the caricature. The two women talking about the gender of the baby is the normalising effect. The note beyin bedava "brain is for free" is a subtle accusation to the figure in the caricature for not using his brain and expressing unreasonable and improper messages. The sound ttrrr, ttrr, ttrr exhibits an effort to express that his brain is an old, faulty machine which functions improperly as a new and state of the art machine would run silently. The caricature has an offensive tone and serves the function of solidarity as the reader laughs at the distorted reasoning of the male figure in the caricature and the incongruity in associating pregnancy with prostitution. The reader is positioned as superior. The people who laugh at this caricature know that there are other people who can read the hidden message and feel the same way, and this creates a sense of solidarity. The male figure represents the other people that are ridiculously unwise. The caricature also is a means to help women to cope with the problem. In short, it can be argued that this caricature, similarly to the previous ones, serves the functions of solidarity and satisfying psychological needs.

The caricature below (Figure 4) is introduced with the caption "It was claimed that a faculty member in İzzet Baysal University asked women students to stand up first and then 
insulted the ones who stood up with the words: "You are hussy. When did you become a woman?" (Kaya 2016). The caricature portrays the scene in the classroom. The answer of one of the woman students, which reads "And when did you become lowbrow?", represents the anger of Turkish women because of the impositions about the matter of virginity. As mentioned, the word woman is associated with virginity. It is problematic for a woman to define herself as a 'woman' because of this matter, and that is why the word woman can be used as insult. The physical appearance of the faculty member tells a lot about his lifestyle. His hairstyle and his moustache are of typical styling popular among unenlightened people who live a life led by orthodox interpretations of religion. He is wearing old fashioned clothes which do not fit well; the jacket is too tight and the trouser hems are too short. His feet are sketched disproportionately smaller as compared to his body on purpose to make him look wretched and ridiculous. The caricature has an offensive tone and creates solidarity among 'the wise' who laugh at the perceptions of the lowbrow people who are stuck with the idea that virginity is the only criterion to womanhood. It also provides laughter and thus relief. This caricature also serves the functions of solidarity and satisfying psychological needs.

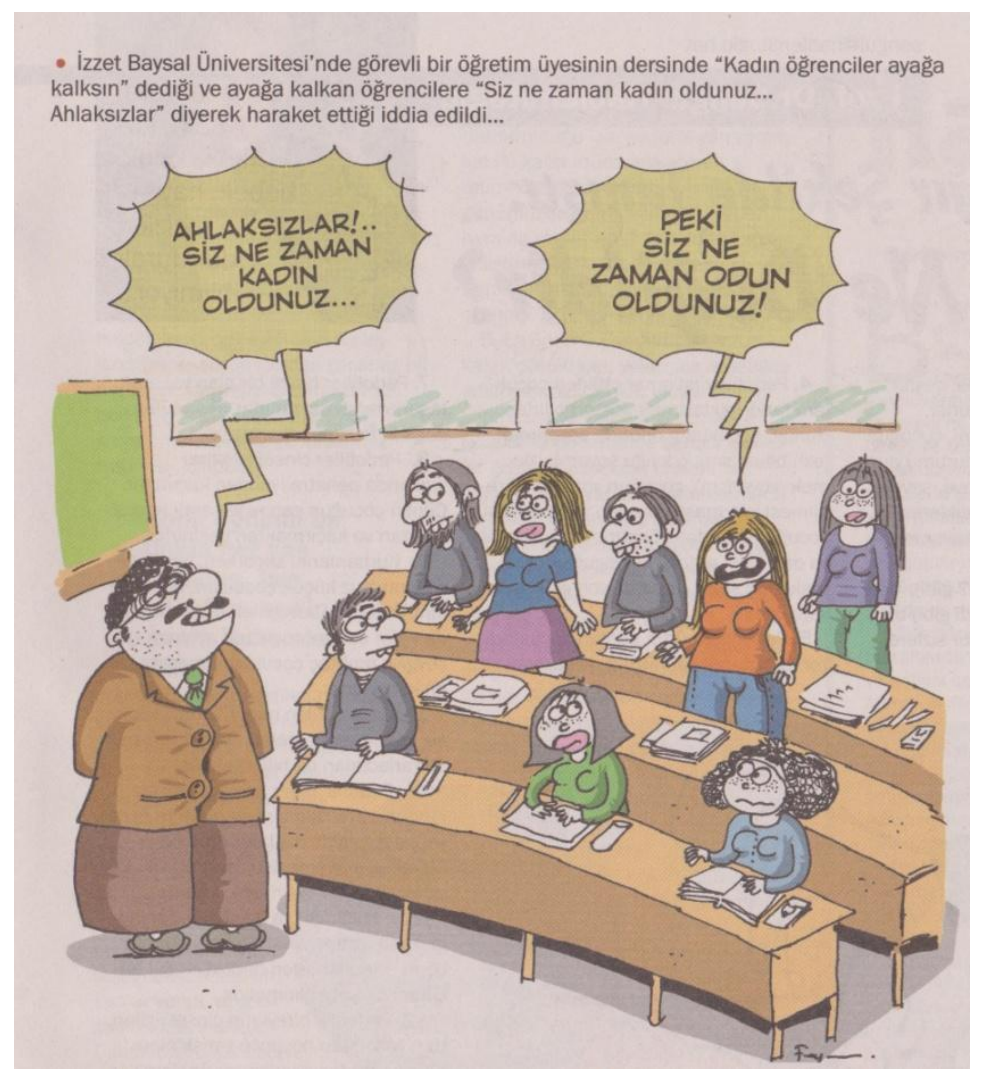

Figure 4. "You are hussy. When did you become a woman?" (Bayan Yanı Humour Magazine, 2016, May, 53: 3, reprinted with the permission of Feyhan Güver, the creator of the caricature.)

The caricature in Figure 5 is another subtle accusation directed at the government for utilising religion to draw the boundaries of women and their relations with men. The caption on the left says: "The Directorate of Religious Affairs gave a fatwa. Engaged couples should not hold hands or stay alone". This caption points to an article in the February issue of the monthly magazine published by the directorate. The article suggested that engaged couples should not hold hands and stay alone in a place where there is no one else (Hürriyet Haber 2015). What is implied by the fatwa is that, if men and women hold hands or stay alone, they can become 
prone to sexual intercourse before getting married, which is against the moral conduct of the culture. The Directorate of Religious Affairs is a government body and hence the government is held accountable for the announcements it makes. What is suggested by the Directorate and what is portrayed in the caricature, however, are not the same thing. The Directorate does not suggest that engaged couples should not walk together; the suggestion is that engaged couples should not stay alone, for example, in a room where there is no one else. As it is a natural tendency to exaggerate something in order to make it seem ridiculous, an engaged couple is portrayed as walking together with an imam walking in between in the caricature. There are many factors that denote that he is an imam. The context provides the first key as imams are the public officials working for the Directorate of Religious Affairs and thus the ones who should make sure that the fatwa is put into practice. He is wearing a cap, a vestment and a shalwar which reflect typical dressing style of imams. He has a long beard and a moustache. The imam functions as an auditor. Especially the man is furious about the practice as he is physically separated from his fiancé by a stranger, an imam, who symbolises religion and the government. What is depicted in the caricature is an extreme violation: a couple walking with an imam in between, where the reaction of the man "what is this ..." is the normalising factor. The caricature has an offensive tone just like other samples of political humour analysed in the study, and indicates that the government is so involved in intimate matters that its intervention is physically felt between couples. The caricature serves the function of satisfying a psychological need: the need to laugh at a situation that causes distress. It presents a fictional situation and turns a threatening situation into an absurd and ridiculous one. It also serves the function of solidarity as the readers feel superior as part of the group, which consists of wise people laughing at the ridiculous imam or the government he represents.

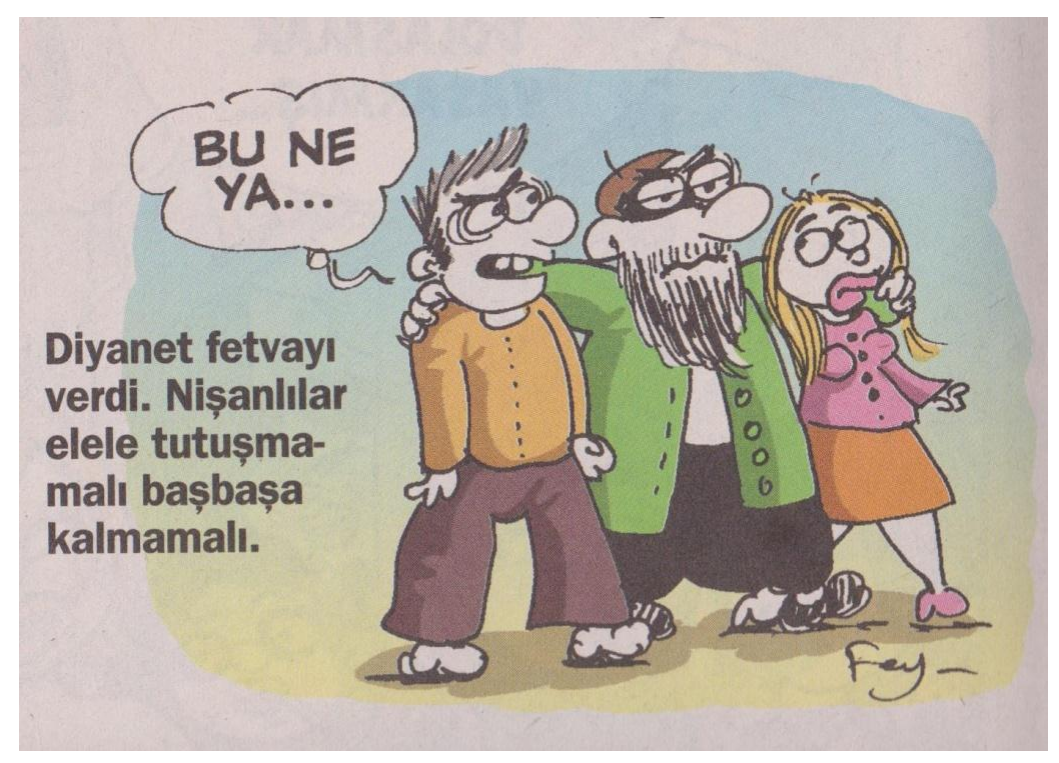

Figure 5. "What is this ..." (Bayan Yanı Humour Magazine, 2016, January, 49: 2, reprinted with the permission of Feyhan Güver, the creator of the caricature.)

The last caricature included in the sample (Figure 6) summarises the main lines of criticism reflected in the humour magazine. The former Prime Minister of Turkey Ahmet Davutoğlu is depicted on a pile of murdered women. He is waving the Turkish flag proudly, as if he had gained a victory. The implied message is that the government purposefully turned a blind eye on the issue of the murders of women as this situation served its strategic purposes. The balloons all around the pile from the bottom left to the right say: "I will spit on the world in which prostitution is called freedom..."; "You cannot make men and women equal!"; "The 
media is dramatising the events!"; "We are living in a Muslim country..."; "A rapist is more innocent than a woman who has an abortion"; "Good conduct abatement!"; "Honour abatement!"; "Disposition!"; "Equality of women and men leads to sexual perversion!"; "Let them boil over with rage for mini skirt and décolleté!"; "Why haven't they controlled their daughter!"; and "Working women lay the grounds for adultery..." All the utterances in the balloons correspond to real quotations of many well-known government or pro-government figures. Also, the fact that the caricaturist criticises these figures by referring to their quotations, but without depicting who uttered them, can be interpreted as a strategic effort to balance the offensive tone of the caricature. The use of echo as a way of irony (Wilson 2006; Wilson \& Sperber 2012) can also be observed in this caricature as the caricaturist simply echoes utterances of outstanding figures as a way of expressing her criticism with women politics and to guide her audience to see the absurdity in the way government figures, who are supposed to protect women rights, make statements that, in a way, hamper or sabotage the development of women's rights in Turkey. By doing so, the caricaturist also mocks the attitudes of the people with the expectation that the government will enhance women's rights. Only the former Prime Minister of Turkey Ahmet Davutoğlu is depicted in the caricature on the top of the figure, which can be interpreted as the caricaturist's way of holding the government responsible for what women suffer by positioning the president of that time as the dominant figure in the composition of the image implies (Kress \& Van Leuwen 2006).

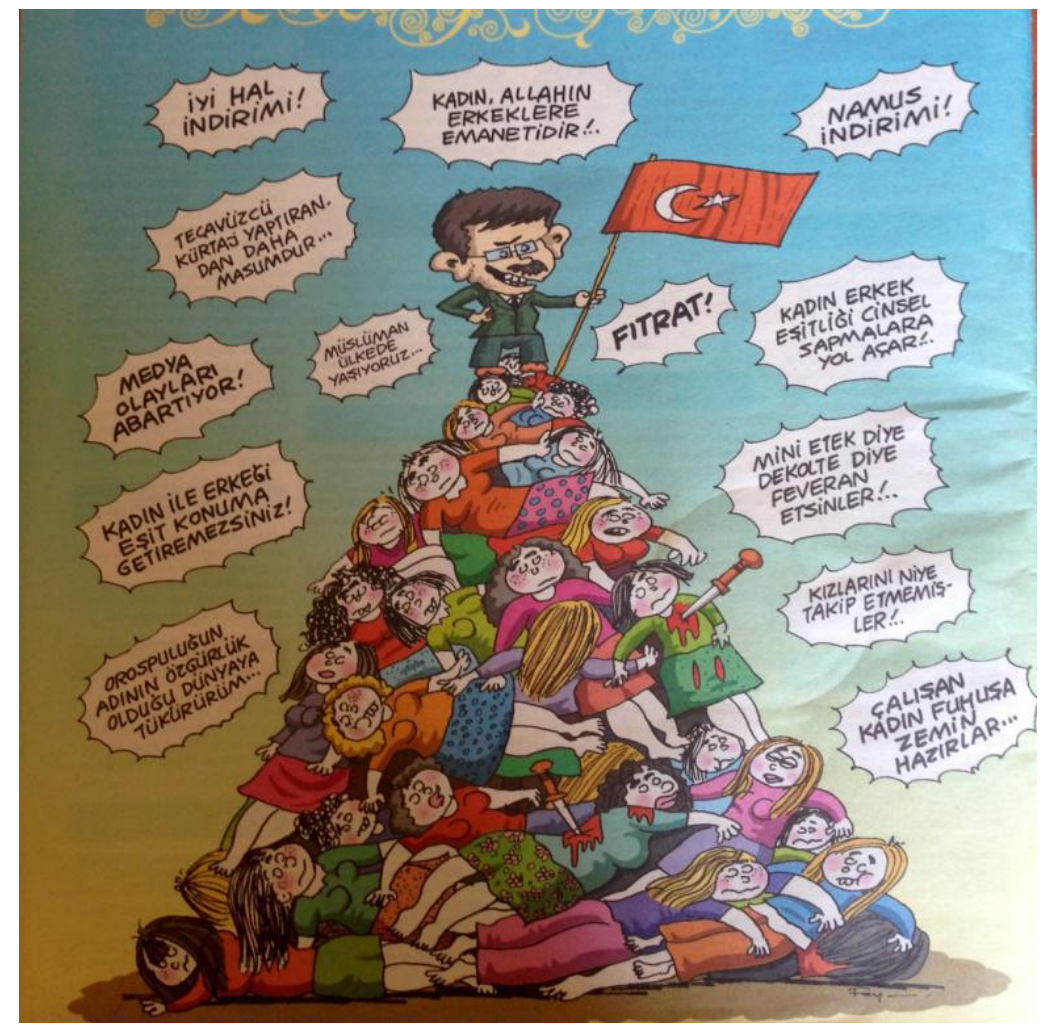

Figure 6. "God entrusts women to men." (Bayan Yanı Humour Magazine, 2015, March, 40: 64, reprinted with the permission of Feyhan Güver, the creator of the caricature.)

The reference in the first balloon, "I will spit on the world in which prostitution is called freedom..." has already been analysed in the section devoted to Figure 3. The second balloon "You cannot make men and women equal!" is criticism directed at the current president of Turkey as he made this statement. He justified his point with the argument that it is against disposition and that feminists reject maternity. The words "The media is dramatising the 
events!" belongs to Fatma Şahin, the Minister of Family and Social Policies in the third cabinet of Erdoğan, when she was asked about the murders of women. She asserted that the public opinion on murders was led by selective perception and that the media was dramatising the events. The next balloon points to a criticism to the defence argument of a chief of police in the dock in a rape case of a fourteen year old girl. He said "Our Prophet had similar marriages. We are living in a Muslim country", which was his effort for legitimising a rape of a young girl by abusing religion (T24 2013). The balloon about abortion is a direct quotation from Ayhan Sefer Üstün, a JDP legislator and Vice President of JDP Human Right Commission. He made the statement when abortion was under discussion. When the cases of rape victims were given as examples by opposing groups as to why abortion should not be banned, he said "Rape victims should not have abortions; women were raped in Bosnia but they gave birth". Recep Akdağ, the former Minister of Health, announced that rape victims should give birth to their babies and that the government would look after the babies if necessary during the same period (Tolunay 2014). Melih Gökçek, the Mayor of Ankara, made similar statements such as "If a woman is raped, why would the child die, the mother should die" and "Women should be well-behaved; then, they will not have to have abortions" (Kasap 2013: 39-40).

The captions 'good conduct abatement' and 'honour abatement' constitute an accusation to the judicial system in the adjudication of men who killed women, their wives in most cases. Men are granted good conduct abatement for wearing a suit and behaving well during formal court proceedings, for example, and in many cases murderers of women receive abatements. Honour abatements are also controversial, as they give reduced sentences to crimes committed in the name of honour, or as with the claim of provocation they give the public the impression that violence is permissible in some cases (Yildiz 2015). The claim that the murdered woman was wearing white leggings and a white t-shirt or that she insulted the murderer are just two examples why murderers of women were granted honour abatements (Diken 2014). The balloon 'Disposition' is a reference to the words of Uğur Işılak, a musician and a JDP legislator: "Women are disposed to belong to men; I own, you belong" (Evrensel 2015); Uğur Iş1lak is not the only person who claims that men and women cannot be equal because of the disposition of each gender. The sentence "Equality of women and men leads to sexual perversion!" is a summary of the words of Ali Bulaç, a journalist who makes controversial comments very often (Ne Diyor 2013). "Let them boil over with rage for mini skirt and décolleté!" are part of the President Erdoğan's speech that he made at the opening ceremony of the dormitories of TÜRGEV (Turkish Youth and Education Service Foundation), which continued as "We will continue to raise young who adopt faith and culture" (Milliyet 2015). The statements of Celalettin Cerrah, the former chief of police of Istanbul, is the reason the balloon "Why haven't they controlled their daughter!" is included in the page. He said these words in relation to the murder of Münevver Karabulut, an eighteen year old girl whose body was decapitated and left in pieces in a garbage bin by her boyfriend. His statements indicated that her death was the fault of her parents who let her have a boyfriend and spend time with him, even in the late hours (Oran 2015). "Working women lay the grounds for adultery", the last balloon belongs to Nurettin Y1ld1z, the President of the Social Fabric Foundation, with the justifications that the working women neglect their husbands and the husbands become prone to adultery, the women's male colleagues can assault her, and that she would not want to give birth (Köklü n.d.).

The caricature has a very offensive tone. Each balloon and caption represents a violation and the normalising factor is that women murders have unfortunately become a part of the daily routine in the country. Turkish people have become inured to hearing about women murders. The caricature serves the function of solidarity as it invites the reader to feel superior to the other (i.e. the government) and to laugh at the unfortunate and unreasonable statements 
of governmental or pro-government figures. The caricaturist also mocks the attitudes of the people with the expectation that the government will enhance women's rights. Therefore, this caricature can be read as a criticism to the voters of the JDP. It also serves the function of satisfying a psychological need as it helps women to laugh at a situation that is hard to cope with in reality. It should be stated that the JDP government, as mentioned in the literature review, initiated very important reforms in terms of gender politics as part of the attempts to a European Union membership. Obligatory women shelters for municipalities with more than 50,000 inhabitants, the formation of Parliamentary Commission for the Equality of Opportunity for Women and Men, the change in the penal code and the resulting recognition of sexual crimes as 'crimes against the individuals/crimes against the inviolability of sexual integrity, termination of provisions that provided rapists with the possibility of avoiding legal punishment by marrying their victims and elimination of discrimination against non-virgin and unmarried women were some of the very important steps (Coşar \& Yeğenoğlu 2011: 562). The extension of the duration of the paid leave for working women after giving birth and the establishment of 'family courts' and a parliamentary commission to investigate and solve the problem of 'honour' killings were other noteworthy developments (Çitak \& Tür 2008: 456). The criticisms reflected in the caricature focus on the rhetoric of the government and progovernment figures and the patriarchal values reflected in this rhetoric. The balloons and captions included in the caricature imply that the government underestimates women murders or maybe sees them as 'natural' with the idea that women are entrusted to men by God, they belong to men, and they can never be equal because of their disposition. The balloons and captions summarise an approval of the domination of men. They also connote that the government encourages the idea that, as we live in a Muslim country, women should not work and should be monitored by their parents or husbands, as they cannot be independent individuals. The government's perception of feminists is reflected in the balloon related to wearing miniskirts. Feminists are positioned as women whose only demand in terms of freedom is just the freedom to wear miniskirts or décolleté, as exposing themselves is the only thing that matters to them, and it is this balloon that indirectly tells that the government has a shallow understanding of feminism and feminists in Turkey. The captions 'good conduct abatement' and 'honour abatement' are two keywords where the accusation against the government of imposing and nurturing patriarchal and religious values and not protecting the women can be read.

\section{Discussion and conclusion}

It can be argued that the tendency for observational humour is obvious in the political caricatures analysed in the present study. Each caricature was introduced with a caption that contextualised the frame within which the caricature should be interpreted. These captions are needed as the political caricatures were based on recent political developments and practices, and could only be commented on with the knowledge of actualities.

As to the functions of political humour in the magazine, it has been found that humour is used to create solidarity and to help to cope with distressing situations in all the political caricatures analysed. The use of humour with the purpose of executing control is non-existent in this sample of political caricatures. One possible explanation for this might be the tendency to use humour with an attempt to execute control either when there is a symmetrical relationship or in the form of down joking when there is an asymmetrical relationship (Coser 1960). However, in political humour, the interlocutors do not have a symmetrical relationship in terms of power. It is usually the target in the caricature (a politician or a government figure) who is more powerful, not the creator of the caricature. 
The offensiveness observed in the humour of the intimate was a natural outcome of political humour. As Cicero argues, humour is used to "point out and designate something offensive in an inoffensive manner" (Perks 2012: 127). Political dissent related to politics of the intimate has an offensive tone and humour was the means in which this negative and offensive content was turned into a less offensive and acceptable format in the samples analysed. The norms imposed on women were challenged by women creators of humorous content with an attempt to convince the public that it is their interpretation of reality that is legitimate, not the interpretations reflected by the social engineering policies of the government. Samples of humour in the present study also demonstrated in what ways humour was utilised to lead the public to question the effectiveness of political decisions and practices related to women by pointing to the outcomes of these practices by portraying fictional cases.

The humour of the intimate analysed in the study was also a sign of women's need to regain self-respect and the spirit of freedom by at least feeling that they could stand up and speak for themselves. The anger that was disguised with the help of humour indicated that humour was used as a safe release of aggressiveness against circumstances that is beyond control (Badarneh 2011: 306, 307). The offensive content that was not possible to voice against the government and pro-government figures could be expressed in a daring tone as humour is often perceived as harmless and playful (Davies 1998: 175).

\section{Acknowledgements}

The author of this paper would like to extent her deepest gratitude to Feyhan Güver, the creator of the caricatures analysed in this study, as well as the Leman Humour Magazine and Bayan Yanı Humour Magazine administrations for their collaboration and permission to publish the caricatures.

\section{References}

Acar, F. \& Altunok G. (2013). 'The 'politics of intimate' at the intersection of neo-liberalism and neo-conservatism in contemporary Turkey.' Women's Studies International Forum 41, pp. 14-23.

Arat, Y. (2010). 'Religion, politics and gender equality in Turkey: Implications of a democratic paradox.' Third World Quarterly 31(6), pp. 869-884.

Badarneh, A. M. (2011). 'Carnivalesque politics: A Bakhtinian case study of contemporary Arab political humour.' Humor: International Journal of Humour Research 24(3), pp. 305-327.

Barthes, R. (1966). 'Introduction à l'analyse structurale du récit' [Introduction to the structural analysis of the narrative.]. Communications 3, pp. 1-27.

Barthes, R. (1977). Image, Music, Text. New York: Hill and Wang.

Bianet, F. (2013) '\#direnhamile (\#resistpregnant)'. Bianet. Published July 25, 2013. http://m.bianet.org/english/gender/148738-direnhamile-resistpregnant.

Boxer, D. \& Florencia C. (1997). 'From bonding to biting: Conversational joking and identity display.' Journal of Pragmatics 27, pp. 275-294.

Brodzinsky, M. D., Barnet, K. \& Aiello, J. R. (1981). 'Sex of subject and gender identity as factors in humour appreciation.' Sex Roles 7(5), pp. 561-573.

Buijzen, M. \& Valkenburg Patti M. (2004). 'Developing a typology of humour in audiovisual media.' Media Psychology 6(2), pp. 147-167.

Çitak, Z. \& Tür, Ö. (2008). 'Women between tradition and change: The justice and development party experience in Turkey.' Middle Eastern Studies 44(3), pp. 455-469. 
Coser, R. (1960). 'Laughter among colleagues: A study of humour among the staff of a mental hospital.' Psychiatry 23(1), pp. 81-95

Coşar, S. \& Yeğenoğlu, M. (2011). 'New grounds for patriarchy in Turkey? Gender policy in the age of JDP.' South European Society and Politics 16(4), pp. 555-573.

Davies, C. (1998). Jokes and their Relation to Society. Berlin: Mouton de Gruyter.

Diken. (2014). 'Tahrik indirimi yeni kadın cinayetlerine davetiye çıkarıyor [Honour abatements open the way to new women murders.] Published August 1, 2014.

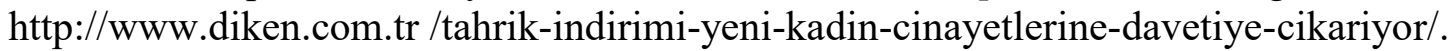

Engineer, A. A. (2008). Rights of Women in Islam. New Delhi: Sterling Publishers.

Evrensel. (2015). 'Erdoğan'ın şarkıcısı: Kadının fitratı erkeğe ait olmaktır [Erdoğan's singer: Women are disposed to belong to men.] Published April 9, 2015. https://www.evrensel. net/ haber/109990/erdoganin-sarkicisi-kadinin-fitrati-erkege-ait-olmaktir.

Greenbaum, A. (1997). 'Women's comic voices: The art and craft of female humour.' American Studies 38(1), pp. 117-138.

Hamdan, Amani. 2005. 'Women and education in Saudi Arabia: Challenges and achievements.' International Education Journal, 6(1), pp. 42-64.

Hausmann, R., Tyson, L. D. \& Zahidi, S. (2006). The Global Gender Gap Report 2006. http://www3.weforum. Org /docs /WEF_Gender Gap_Report_2006.pdf.

Hay, Jennifer. (1995). Gender and Humour: Beyond a Joke. New Zealand: Victoria University of Wellington, MA thesis.

Herbert, W. L. \& Jarvis, F. V. (2013). Marriage Counselling in the Community: The Commonwealth and International Library: Problems and Progress in Human Development. UK: Pergamon.

Hürriyer Haber. (2015). 'Diyanet'ten nişanlı çiftlere: Elele tutuşmayın, sadece konuşun [ From the directorate of religious affairs to engaged couples: Do not hold hands, just speak.]' Published February 14, 2015. http://www. hurriyet.com.tr/diyanetten-nisanli-ciftlere-elele-tutusmayin-sadece-konusun-28199592.

İlkkaracan, P. (1998). 'Exploring the context of women's sexuality in eastern Turkey.' Reproductive Health Matters 6(12): 66-75.

İnce, H. O., Yaral1, A. \& Özsel D. (2009). 'Customary killings in Turkey and Turkish modernization.' Middle Eastern Studies 45(4), pp. 537-551.

Johnson, A. M. (1992). 'Language ability and sex affect humour appreciation.' Perceptual and Motor Skills 75, pp. 571-581.

Kasap, T. (2013). Women's Wombs as a "Biopolitical Space" in the Context of Biopolitics of Abortion in Turkey. Hungary: Central European University, MA thesis.

Kaya, A. (2015). 'Islamisation of Turkey under the JDP rule: Empowering family, faith and charity.' South European Society and Politics 20(1), pp. 47-69.

Kaya, S. (2016). 'Siz ne zaman kadın oldunuz, ahlaksızlar [When did you become a woman?]' Haber Hürriyeti. Published April 25, 2016. http://www.haberhurriyeti.com/siz-ne-zamankadin-oldunuz-ahlaksizlar-168728.html.

Köklü, G. n.d. 'Kadınlarla ilgili inanılmaz fetvalar [Unbelievable fatwas about women.] Mynet. Accessed August 15, 2016. http:// trend. mynet.com/kadinlarla-ilgili-inanilmaz-fetvalar1043400.

Kotthoff, H. (2006). 'Gender and humour: The state of the art.' Journal of Pragmatics 38, pp. 4-25.

Kress, R., G. \& Leeuwen, T. V. (2006). Reading Images: The Grammar of Visual Design. USA: Routledge.

Milliyet. (2015). 'Varsın onlar inadına dekolte inadına mini etek desinler [Let them boil over with rage for mini skirt and décolleté.]' Published February 25, 2015. 
http://www.milliyet.com.tr/-varsin-onlar-inadinadekolte/siyaset/detay/2019249/default.htm.

Ne Diyor. (2013). 'Ali Bulaç: Kadın-erkek eşitliği neslin sonu olur [Ali Bulaç: Women-men equality will be the end of the generation.] Published August 19, 2013. http://nediyor.com /ali-bulac-kadin-erkek-esitligi-neslin-sonu-olur/.

Onar, N. F. \& Müftüler-Baç, M. (2011). 'The adultery and headscarf debates in Turkey: Fusing "EU-niversal" and "alternative" modernities?' Women's Studies International Forum 34, pp. 378-389.

Oran, B. (2015). 'Özgecan'ın katilini kim azmettirdi [Who abated Özgecan's murderer.]' Radikal. Published February 20, 2015. http://www.radikal.com.tr/ yazarlar/baskinoran/ozgecanin-katilini-kim-azmettirdi-1297238/.

Par, K. (2014). 'Evlenmeden hamile kalırım diyenin hürriyetine tükürürüm [I will spit on the freedom of the one who says I can get pregnant before getting married.]' Habertürk. Published, December 14, 2014. http://www.haberturk. com/ gundem/ haber/ 1018955evlenmeden-hamile-kalirim-diyenin-hurriyetine-tukururum.

Penn, G. (2000). 'Semiotic analysis of still images.' in Bauer, W M. \& Gaskell, G. (eds.), Qualitative Researching with Text, Image and Sound, London: Sage Publications, pp. 227-245.

Perks, L. (2012). 'The ancient roots of humour theory.' Humor: International Journal of Humor Research, 25(2), pp. 119-132.

Sebeok, T. A. \& Danesi, M. (2000). The Forms of Meaning: Modelling Systems Theory and Semiotic Analysis. Berlin: Walter de Gruyter GmbH.

Tolunay, Ö. (2014). 'Women in Erdoğan's Turkey'. New Politics. Accessed August 16, 2016. http://newpol.org/content/women-erdoğan's-turkey.

$\mathrm{T}$ 24. 2013. Çocuğa cinsel istismar savunması: Peygamberimizin benzer evlilikleri var [Defense for sexual abuse to a child: Our prophet had similar marriages.] Published September 10, 2013. http:// t24. com.tr/haber/cocuga-cinsel-istismar-savunmasipeygamberimizin-benzer-evlilikleri-var,239152.

Tsakona, V. \& Popa, E. D. (2011). 'Humour in politics and the politics of humour: An introduction.' in Tsakona, V. \& Popa, E. D (eds.), Studies in Political Humour: In Between Political Critique and Public Entertainment, Amsterdam: John Benjamins, pp. 130.

Turam, B. (2008). 'Turkish women divided by politics.' International Feminist Journal of Politics 10(4), pp. 475-494.

Unal, D. \& Cindoğlu, D. (2013). 'Reproductive citizenship in Turkey: Abortion chronicles.' Women's Studies International Forum 38, pp. 21-31.

Veatch, C. Thomas. (1998). 'A theory of humour.' Humor: International Journal of Humor Research 11(2), pp. 161-215.

Weinberger, M. \& Gulas, C. S. (1992). 'The impact of humour in advertising: A review.' Journal of Advertising 21(4), pp. 35-59.

Wilson, D. (2006). 'The pragmatics of verbal irony: Echo or pretence?' Lingua 116, pp. 172243.

Wilson, D. \& Sperber, D. (2012). 'Explaining irony', in Wilson, D. \& Sperber, D. (eds.), Meaning and Relevance, Cambridge: Cambridge University Press, pp. 123-145.

World Economic Forum. (2016). The Global Gender Gap Report 2015. Accessed April 1, 2016.

http://www3.weforum.org/docs/GGGR2015/cover.pdf.

Yildiz, E. 'A discourse that fuels violence: Akp and the culture of permissiveness toward violence against women in Turkey.' Lefteast. Published March 4, 2015. http://www.criticatac.ro/lefteast/a-discourse-that-fuels-violence. 